Article

\title{
One-Pot Liquid-Phase Catalytic Conversion of Ethanol to 1-Butanol over Aluminium Oxide-The Effect of the Active Metal on the Selectivity
}

\author{
Toni Riittonen ${ }^{1{ }^{*} \text {, Esa Toukoniitty }}{ }^{1,2}$, Dipak Kumar Madnani ${ }^{1}$, Anne-Riikka Leino ${ }^{3}$, \\ Krisztian Kordas ${ }^{3}$, Maria Szabo ${ }^{4}$, Andras Sapi ${ }^{4}$, Kalle Arve ${ }^{1}$, Johan Wärnå ${ }^{1}$ and \\ Jyri-Pekka Mikkola ${ }^{1,5}$
}

1 Laboratory of Industrial Chemistry and Reaction Engineering, Process Chemistry Centre, Åbo Akademi University, Turku-Åbo FI-20500, Finland;

E-Mails: esa.toukoniitty@metropolia.fi (E.T.); dipakmadnani@gmail.com (D.K.M.); kalle.arve@abo.fi (K.A.); johan.warna@abo.fi (J.W.); jpmikkol@abo.fi (J.-P.M.)

2 Helsinki Metropolia University of Applied Sciences, P.O. Box 4000 (Bulevardi 31), Metropolia FI-00079, Finland

3 Microelectronics and Materials Physics Laboratories, Department of Electrical and Information Engineering, University of Oulu, P.O. Box 4500, FI-90014, Finland;

E-Mails: anneriik@ee.oulu.fi (A.-R.L.); krisztian.kordas@ee.oulu.fi (K.K.)

4 Applied and Environmental Chemistry Department, University of Szeged, Szeged 6723,

Rerrich Béla tér 1, Hungary; E-Mails: szmaria@chem.u-szeged.hu (M.S.); andras.sapi@ee.oulu.fi (A.S.)

5 Department of Chemistry, Technical Chemistry, Chemical-Biological Center, Umeå University, Umeå 90187, Sweden

* Author to whom correspondence should be addressed; E-Mail: triitton@abo.fi.

Received: 21 September 2011; in revised form: 24 November 2011 / Accepted: 4 January 2012 / Published: 13 January 2012

\footnotetext{
Abstract: Direct catalytic valorization of bioethanol to 1-butanol over different alumina supported catalysts was studied. Thirteen (13) heterogeneous catalysts were screened in search for the optimal material composition for direct one-pot conversion of ethanol to 1-butanol. For the most promising catalyst, a $25 \%$ ethanol conversion with $80 \%$ selectivity (among liquid carbon products) to 1-butanol could be reached at $250{ }^{\circ} \mathrm{C}$. Additionally, the reaction kinetics and mechanisms were further investigated upon use of the most suitable catalyst candidate.
} 
Keywords: heterogeneous catalyst; one-pot; bioethanol; 1-butanol; alumina

\section{Introduction}

Ethanol is currently the biggest liquid biofuel contributor worldwide. The first generation bioethanol production often employs edible food crops as raw materials and thus gives rise to increased food prices by competing with human food and animal feed production. In order to overcome this problem, the second generation biofuels are increasingly prepared from non-edible raw materials, e.g., wood, agricultural waste and other lignocellulosic materials [1-3]. In Nordic countries, the biofuel research focuses heavily on the use of woody biomass as a raw material for bioethanol and other biofuels. Finland and Sweden have the largest wood resources in Europe per capita, which makes wood a natural choice of raw material. However, there are still many problems associated with the use of ethanol fuel in internal combustion engines, e.g., its water solubility, corrosivity and the differences in its fuel properties compared to modern gasoline. These problems have to be overcome before the full potential of bioethanol can be utilized.

In order to overcome the disadvantages of ethanol as a fuel, catalytic valorization of ethanol to higher alcohols, e.g., 1-butanol can be carried out. Compared to ethanol, 1-butanol (or $n$-butanol) has several advantages: it can be burned in the existing gasoline engines without practically any engine or car modifications and it has higher energy content and air-to-fuel ratio than ethanol making 1-butanol an excellent green replacement for a modern gasoline. In summary, the properties of 1-butanol closely resemble the properties of modern gasoline (Table 1).

Table 1. Chemical and physical properties of gasoline, diesel, 1-butanol and ethanol. Data is reproduced from reference [4].

\begin{tabular}{cccccc}
\hline Fuel & $\begin{array}{c}\text { Energy density/ } \\
\text { MJ L }^{-\mathbf{1}}\end{array}$ & Air-to-fuel ratio & $\begin{array}{c}\text { Energy content/ } \\
\text { Btu/USgallon }\end{array}$ & RON $^{\text {a }}$ & $\begin{array}{c}\text { Water } \\
\text { solubility/\% }\end{array}$ \\
\hline Gasoline & 32 & 14.6 & 114,000 & $81-89$ & negligible \\
Diesel & 35.5 & 14.7 & 130,000 & - & negligible \\
1-butanol & 29.2 & 11.12 & 105,000 & 78 & 7 \\
Ethanol & 19.6 & 8.94 & 84,000 & 96 & 100 \\
\hline \multicolumn{5}{c}{ a Research octane number. }
\end{tabular}

Furthermore, another advantage of 1-butanol is the fact that it can be distributed via the existing pipelines for gasoline. In the end, it is an advantage if the consumer does not notice a difference when using 1-butanol as a fuel instead of modern gasoline in a gasoline driven vehicle.

1-Butanol is an important chemical feedstock and around 2.9 million tons was utilized by the industry in 2005. 1-Butanol can be synthesized by several routes such as the oxo-process [5-10], the acetaldehyde method or by fermentation.

In the open literature, only a few reports describe the direct catalytic dimerisation or conversion of ethanol to 1-butanol and other hydrocarbons [11-16]. These described technologies suggest a two-phase process where ethanol vapor is passed through a solid catalyst packed in a fixed bed. The 
reaction temperatures vary from $200{ }^{\circ} \mathrm{C}$ up to $450{ }^{\circ} \mathrm{C}$, with a relatively low conversion (10-20\%) and selectivity approaching $70 \%$. In the recent literature, a novel catalytic process utilizing a non-stoichiometric hydroxyapatite was found to be very promising [11,15]. In addition, solid bases [15], some zeolites [14], and supported metals (e.g., Ni, Co) [12] have been reported to convert ethanol to 1-butanol. To the best of our knowledge, until today no reports exist that describe a liquid-phase process for this particular reaction.

The conversion of biomass to valuable chemicals is a multi-step processes containing both chemical and catalytic reaction steps. By applying traditional approach and carrying out these conversions in separate reactors followed by subsequent separation, purification and drying steps would become complicated and expensive to realize in practice. Furthermore, in such a multi-step process, a lower yield of the end product with large amount of waste would be expected. One-pot reactions are capable of addressing these issues which involve multiple catalytic reaction steps in a single reactor unit. In this work, we demonstrate that conversion of ethanol to 1-butanol in one-pot manner is possible with high selectivity and conversion. The reaction was carried out in one pot without additional solvents in the absence of any catalyst pretreatments. For the most promising catalyst, a $25 \%$ ethanol conversion with $80 \%$ selectivity (among liquid carbon products) to 1-butanol could be reached.

For the catalytic conversion of liquid ethanol to 1-butanol several alumina supported heterogeneous catalysts were screened by applying a direct one-pot approach using only ethanol, catalyst and heating of the stirred mixture to carry out the reaction. The desired overall reaction scheme is presented in Scheme 1. The results from kinetic and mechanistic studies including catalyst characterization results will be presented here. Reaction schemes are presented in supplementary material.

Scheme 1. Dimerisation of ethanol to 1-butanol.

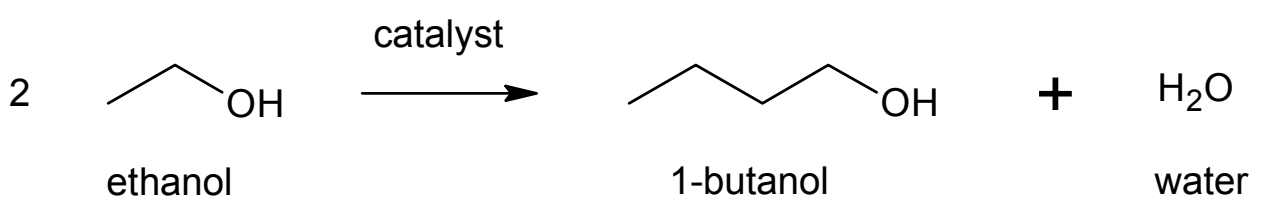

\section{Results and Discussion}

A large selection of heterogeneous alumina supported catalysts were screened for direct one-pot conversion of ethanol to 1-butanol at $250{ }^{\circ} \mathrm{C}$ as described in the experimental section. Catalyst characterization details are reported in Table 2 and preparation procedures in supplementary material. The best catalyst was studied in more detail employing kinetic and mechanistic experiments.

\subsection{Catalyst Screening}

The main products were acetaldehyde, diethyl ether, ethyl acetate, 1-butanol, 1,1-diethoxy ethane, 1-hexanol and 1-octanol which typically accounted for over $90 \%$ of the formed products. Their relative amounts varied depending on the choice of the catalyst. Also traces of other hydrocarbons were formed during some screening experiments. The higher C-6 and C-8 alcohols could be detected during prolonged experiments indicating that the reaction can proceed further from dimers of ethanol as well as to tri- and tetramers of ethanol. No odd number (C-3, C-5, C-7) alcohols were detected in the 
screening experiments (based on GC-MS analysis). This kind of product distribution may be related to so called Guerbet reaction which produces branched alcohols from primary ones [15]. The product composition varied greatly over various tested catalysts. Mini-reactor experiments were used to find out the most selective catalyst (Table 2) for ethanol to 1-butanol production. Typical conversion of ethanol (after $3 \mathrm{~h}$ of reaction) in the mini-reactor screening experiments was approximately $2-5 \%$. In control experiments without a catalyst, the conversion of ethanol remained around $1 \%$ and only acetaldehyde and diethyl ether were formed.

Table 2. Summary of the catalyst characterization results.

\begin{tabular}{|c|c|c|c|c|c|c|c|}
\hline & Catalyst & Code & $\begin{array}{c}\text { Metal } \\
\text { dispersion } \\
(\%)^{a} \\
\end{array}$ & $\begin{array}{c}\text { Metal particle size } \\
\text { (nm), } \mathbf{H}_{2} \\
\text { chemisorption }^{\text {a }}\end{array}$ & $\begin{array}{c}\text { Metal particle } \\
\text { size }(\mathbf{n m})^{\mathbf{b}}, \\
\text { TEM } \\
\end{array}$ & $\begin{array}{c}\text { Metal particle } \\
\text { size }(\mathbf{n m})^{\mathbf{c}} \\
\text { XRD } \\
\end{array}$ & $\begin{array}{c}\text { Surface } \\
\text { Area } \\
\left(\mathbf{m}^{2} / \mathbf{g}\right)^{\mathrm{d}} \\
\end{array}$ \\
\hline 1 & $5 \% \mathrm{Ru} / \mathrm{Al}_{2} \mathrm{O}_{3}$ & H213B & 37.88 & 3.49 & $2.5 \pm 1.1$ & n.m. & 105 \\
\hline 2 & $5 \% \mathrm{Rh} / \mathrm{Al}_{2} \mathrm{O}_{3}$ & G214RA & 54.21 & 2.03 & $2.6 \pm 1.3$ & n.m. & 308 \\
\hline 3 & $5 \% \mathrm{Pd} / \mathrm{Al}_{2} \mathrm{O}_{3}$ & E213R & 17.51 & 6.40 & $3.5 \pm 1.7$ & $4.2 \pm 0.2$ & 127 \\
\hline 4 & $5 \% \mathrm{Pt} / \mathrm{Al}_{2} \mathrm{O}_{3}$ & F214 XSP/D & n.m. & n.m. & $2.5 \pm 1.9$ & $2.8 \pm 0.2$ & n.m. \\
\hline 5 & $0.8 \% \mathrm{Au} / \mathrm{Al}_{2} \mathrm{O}_{3}$ & MINTEK1/BC3 & n.m. & n.m. & n.m. & n.m. & n.m. \\
\hline 6 & $\mathrm{Ni} / \mathrm{Al}_{2} \mathrm{O}_{3}$ & $\begin{array}{c}\text { Crossfield/ } \\
\text { HTC-500 }\end{array}$ & n.m. & n.m. & 8.2 & n.m. & n.m. \\
\hline 7 & $20 \% \mathrm{Ni} / \mathrm{Al}_{2} \mathrm{O}_{3}$ & Self-prepared & n.m. & n.m. & $3.5 \pm 0.2$ & n.m. & 289 \\
\hline 8 & $2 \% \mathrm{Ag} / \mathrm{Al}_{2} \mathrm{O}_{3}$ & Self-prepared & n.m. & n.m. & $5.2 \pm 2.1$ & n.m. & 289 \\
\hline 9 & $4 \% \mathrm{Ag} / \mathrm{Al}_{2} \mathrm{O}_{3}$ & Self-prepared & n.m. & n.m. & $1-5$ and $10-40$ & n.m. & 289 \\
\hline 10 & $6 \% \mathrm{Ag} / \mathrm{Al}_{2} \mathrm{O}_{3}$ & Self-prepared & n.m. & n.m. & n.m. & n.m. & 289 \\
\hline 11 & $1 \% \mathrm{Ru} / \mathrm{Al}_{2} \mathrm{O}_{3}$ & Self-prepared & n.m. & n.m. & n.m. & n.m. & 289 \\
\hline 12 & $2 \% \mathrm{Ru} / \mathrm{Al}_{2} \mathrm{O}_{3}$ & Self-prepared & n.m. & n.m. & n.m. & n.m. & 289 \\
\hline 13 & $5 \% \mathrm{Ru} / \mathrm{Al}_{2} \mathrm{O}_{3}$ & Self-prepared & n.m. & n.m. & $1-7$ and 100 & n.m. & 289 \\
\hline
\end{tabular}

${ }^{a}$ From hydrogen chemisorptions; ${ }^{b}$ Based on transmission electron microscopy (TEM); ${ }^{c}$ Based on X-ray diffraction (XRD); ${ }^{\mathrm{d}}$ Obtained from nitrogen physisorption; n.m. = not measured.

The following qualitative conclusions can be drawn for the formed liquid hydrocarbon products from the catalyst screening experiments which give valuable guidelines for the future catalyst development:

Ru: Commercial 5\% Ru on alumina and self-prepared 1-, 2- and 5\% Ru on alumina were tested (Table 3). 1-butanol selectivity was 30\% when the commercial catalyst was evaluated. The self-prepared Ru-catalysts showed lower selectivity towards 1-butanol when compared to the commercial one but the conversion was much higher. One possible explanation might be the formation of gaseous products over the self-prepared catalysts. A reduced catalyst promoted the formation of diethyl ether. The same catalyst reduction effect was observed for $\mathrm{Ni}$ on alumina catalyst as well. For all catalyst screening experiments, the commercial supported metal catalysts were used as received in unreduced state. TEM and XRD were measured over the self-prepared 5\% Ru on alumina catalyst (Figure 1). 
Table 3. Results obtained with alumina supported Ru catalysts.

\begin{tabular}{|c|c|c|c|c|c|c|c|c|}
\hline \multirow[b]{2}{*}{ Manufactured } & \multirow[b]{2}{*}{ Catalyst } & \multirow{2}{*}{$\begin{array}{l}\text { Product } \\
\text { code }\end{array}$} & \multirow{2}{*}{$\begin{array}{c}\text { Conversion } \\
(\%)\end{array}$} & \multicolumn{5}{|c|}{ Selectivity (\%) } \\
\hline & & & & acetaldehyde & $\begin{array}{c}\text { diethyl } \\
\text { ether }\end{array}$ & $\begin{array}{c}\text { ethyl } \\
\text { acetate }\end{array}$ & 1-butanol & $\begin{array}{c}\text { 1,1-diethoxy } \\
\text { ethane }\end{array}$ \\
\hline Degussa & $5 \% \mathrm{Ru} / \mathrm{Al}_{2} \mathrm{O}_{3}$ & $\mathrm{H} 213 \mathrm{~B} / \mathrm{D}$ & 2 & 8 & 1 & 0 & 30 & 19 \\
\hline La Roche & $1 \% \mathrm{Ru} / \mathrm{Al}_{2} \mathrm{O}_{3}$ & $\begin{array}{c}\text { A } 201 \\
\text { (self-prep.) }\end{array}$ & 8 & 50 & 18 & 0 & $\mathbf{0}$ & 33 \\
\hline La Roche & $2 \% \mathrm{Ru} / \mathrm{Al}_{2} \mathrm{O}_{3}$ & $\begin{array}{c}\text { A } 201 \\
\text { (self-prep.) }\end{array}$ & 11 & 54 & 8 & 0 & 4 & 33 \\
\hline La Roche & $5 \% \mathrm{Ru} / \mathrm{Al}_{2} \mathrm{O}_{3}$ & $\begin{array}{c}\text { A } 201 \\
\text { (self-prep.) }\end{array}$ & 12 & 54 & 3 & 2 & 9 & 31 \\
\hline
\end{tabular}

Figure 1. Transmission electron microscopy (TEM) and X-ray diffraction (XRD) images of self-prepared $5 \mathrm{wt} \% \mathrm{Ru} / \mathrm{Al}_{2} \mathrm{O}_{3}$ catalyst. XRD shows the existence of $\mathrm{RuO}_{2}$ and the particle size distribution varies between 1-7 nm. In addition, particles up to $100 \mathrm{~nm}$ were also found.
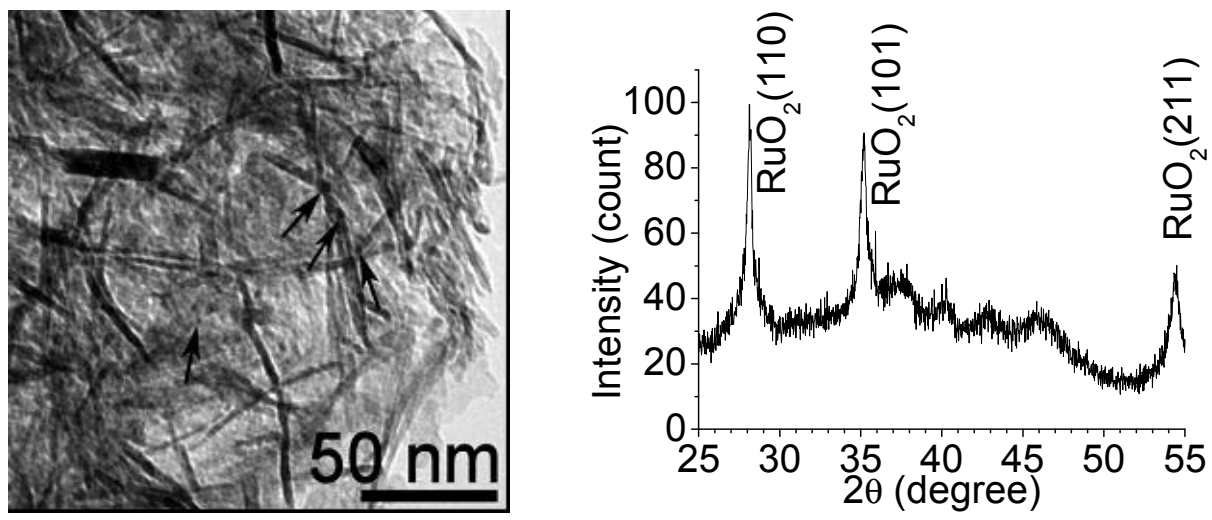

Rh: Commercial 5\% Rh on alumina was tested (Table 4). Rh on alumina produced diethyl ether ( $\mathrm{S}=30 \%$ ) and 1-butanol ( $\mathrm{S}=35 \%$ ). In comparison to ruthenium (Degussa H $213 \mathrm{~B} / \mathrm{D}$ ), rhodium might have a promoting effect on alumina leading to an increase in the catalyst acidity and, thus, higher diethyl ether formation.

Table 4. Results obtained with alumina supported Rh catalyst.

\begin{tabular}{|c|c|c|c|c|c|c|c|c|}
\hline \multirow[b]{2}{*}{ Manufactured } & \multirow[b]{2}{*}{ Catalyst } & \multirow{2}{*}{$\begin{array}{l}\text { Product } \\
\text { code }\end{array}$} & \multirow{2}{*}{$\begin{array}{c}\text { Conversion } \\
(\%)\end{array}$} & \multicolumn{5}{|c|}{ Selectivity (\%) } \\
\hline & & & & acetaldehyde & $\begin{array}{l}\text { diethyl } \\
\text { ether }\end{array}$ & $\begin{array}{c}\text { ethyl } \\
\text { acetate }\end{array}$ & 1-butanol & $\begin{array}{c}\text { 1,1-diethoxy } \\
\text { ethane }\end{array}$ \\
\hline Degussa & $5 \% \mathrm{Rh} / \mathrm{Al}_{2} \mathrm{O}$ & G214 RA/D & 5 & 4 & 41 & 0 & 35 & 4 \\
\hline
\end{tabular}

Pd: Commercial Pd on alumina was screened (Table 5) and the results $\left(\mathrm{S}_{\text {butanol }}=21 \%\right.$ ) follow almost similar behavior with the rhodium, promoting the formation of diethyl ether.

Table 5. Results obtained with alumina supported Pd catalyst.

\begin{tabular}{|c|c|c|c|c|c|c|c|c|}
\hline \multirow[b]{2}{*}{ Manufactured } & \multirow[b]{2}{*}{ Catalyst } & \multirow{2}{*}{$\begin{array}{l}\text { Product } \\
\text { code }\end{array}$} & \multirow{2}{*}{$\begin{array}{c}\text { Conversion } \\
(\%)\end{array}$} & \multicolumn{5}{|c|}{ Selectivity (\%) } \\
\hline & & & & acetaldehyde & $\begin{array}{l}\text { diethyl } \\
\text { ether }\end{array}$ & $\begin{array}{c}\text { ethyl } \\
\text { acetate }\end{array}$ & 1-butanol & $\begin{array}{c}\text { 1,1-diethoxy } \\
\text { ethane }\end{array}$ \\
\hline Degussa & $5 \% \mathrm{Pd} / \mathrm{Al}_{2} \mathrm{O}_{3}$ & E213 R/D & 9 & 3 & 64 & 1 & 21 & 2 \\
\hline
\end{tabular}


Pt: Commercial Pt catalyst was found to contain a positive impact $\left(\mathrm{S}_{\text {butanol }}=37 \%\right)$ on the desired product (Table 6) and, furthermore, the selectivity towards diethyl ether was much lower in comparison to $\mathrm{Pd}$ and $\mathrm{Rh}$.

Table 6. Results obtained with alumina supported Pt catalyst.

\begin{tabular}{|c|c|c|c|c|c|c|c|c|}
\hline \multirow[b]{2}{*}{ Manufactured } & \multirow[b]{2}{*}{ Catalyst } & \multirow{2}{*}{$\begin{array}{l}\text { Product } \\
\text { code }\end{array}$} & \multirow{2}{*}{$\begin{array}{c}\text { Conversion } \\
(\%)\end{array}$} & \multicolumn{5}{|c|}{ Selectivity (\%) } \\
\hline & & & & acetaldehyde & $\begin{array}{l}\text { diethyl } \\
\text { ether }\end{array}$ & $\begin{array}{c}\text { ethyl } \\
\text { acetate }\end{array}$ & 1-butanol & $\begin{array}{c}\text { 1,1-diethoxy } \\
\text { ethane }\end{array}$ \\
\hline Degussa & $5 \% \mathrm{Pt} / \mathrm{Al}_{2} \mathrm{O}_{3}$ & $\mathrm{~F} 214 \mathrm{XSP} / \mathrm{D}$ & 3 & 9 & 10 & 9 & 37 & 8 \\
\hline
\end{tabular}

Ag: The self-prepared silver catalysts were rather inactive towards 1-butanol giving selectivities between 13-20\%. However, also a rather high selectivity to acetaldehyde and 1,1-diethoxy ethane were observed (Table 7). TEM and XRD were measured over the self-prepared $4 \% \mathrm{Ag}$ on alumina catalyst (Figure 2).

Table 7. Results obtained with alumina supported Ag catalysts.

\begin{tabular}{|c|c|c|c|c|c|c|c|c|}
\hline \multirow[b]{2}{*}{ Manufactured } & \multirow[b]{2}{*}{ Catalyst } & \multirow{2}{*}{$\begin{array}{l}\text { Product } \\
\text { code }\end{array}$} & \multirow{2}{*}{$\begin{array}{c}\text { Conversion } \\
(\%)\end{array}$} & \multicolumn{5}{|c|}{ Selectivity (\%) } \\
\hline & & & & acetaldehyde & $\begin{array}{l}\text { diethyl } \\
\text { ether }\end{array}$ & $\begin{array}{c}\text { ethyl } \\
\text { acetate }\end{array}$ & 1-butanol & $\begin{array}{c}\text { 1,1-diethoxy } \\
\text { ethane }\end{array}$ \\
\hline La Roche & $2 \% \mathrm{Ag} / \mathrm{Al}_{2} \mathrm{O}_{3}$ & $\begin{array}{c}\text { A } 201 \\
\text { (self-prep.) }\end{array}$ & 1 & 48 & 12 & 4 & 16 & 20 \\
\hline La Roche & $4 \% \mathrm{Ag} / \mathrm{Al}_{2} \mathrm{O}_{3}$ & $\begin{array}{c}\text { A } 201 \\
\text { (self-prep.) }\end{array}$ & 1 & 49 & 13 & 4 & 13 & 20 \\
\hline La Roche & $6 \% \mathrm{Ag} / \mathrm{Al}_{2} \mathrm{O}_{3}$ & $\begin{array}{c}\text { A } 201 \\
\text { (self-prep.) }\end{array}$ & 2 & 45 & 11 & 6 & 20 & 16 \\
\hline
\end{tabular}

Figure 2. TEM and XRD pictures of self-prepared $4 \mathrm{wt} \% \mathrm{Ag} / \mathrm{Al}_{2} \mathrm{O}_{3}$ catalyst. XRD reveals metallic silver with an average crystal size of $\sim 13 \mathrm{~nm}$. The particle size analysis based on TEM measurements shows a bimodal size distribution with ranges of 1-5 nm and 10-40 nm.
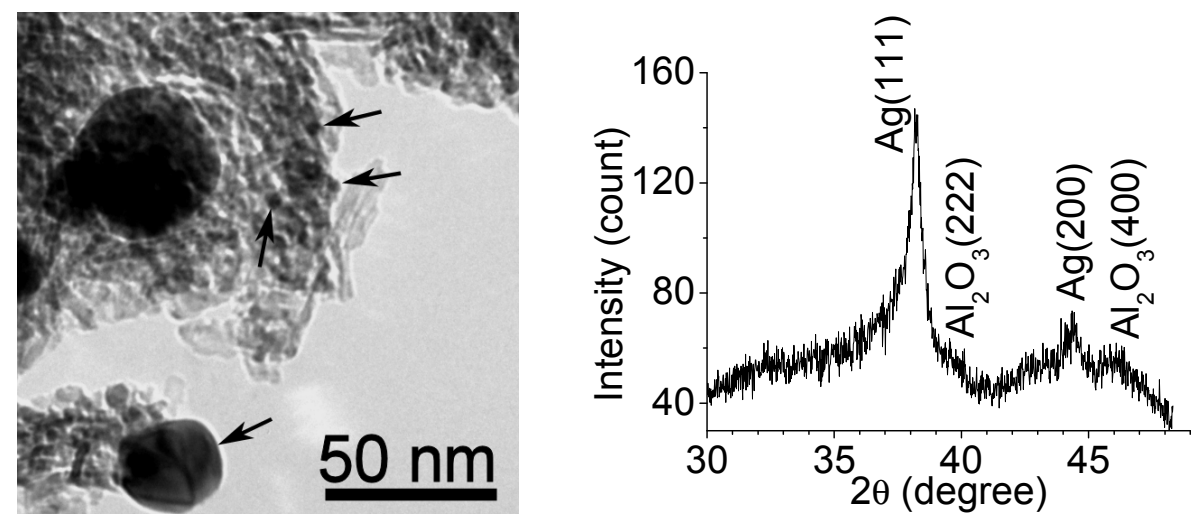

Ni: Two types of nickel catalysts were tested (Table 8). Overall, the commercial HTC-500 (20.7\% $\mathrm{Ni}$ on alumina) was the best catalyst within the whole series of catalysts screened in terms of selectivity (62\%). Also self-prepared $20 \% \mathrm{Ni}$ on alumina (La Roche) showed moderate selectivity (37\%) towards 1-butanol but the conversion was almost four times higher in comparison to the 
HTC-500, producing a significant amount of acetaldehyde. Both nickel catalysts were characterized by means of XRD and TEM (Figures 3 and 4). Interestingly, the self-prepared catalyst shows a considerably smaller particle size distribution and it does not contain any aggregates which are presumed to be inactive parts.

Table 8. Results obtained with alumina supported Ni catalysts.

\begin{tabular}{|c|c|c|c|c|c|c|c|c|}
\hline \multirow[b]{2}{*}{ Manufactured } & \multirow[b]{2}{*}{ Catalyst } & \multirow[b]{2}{*}{$\begin{array}{l}\text { Product } \\
\text { code }\end{array}$} & \multirow[b]{2}{*}{$\begin{array}{c}\text { Conversion } \\
(\%)\end{array}$} & \multicolumn{5}{|c|}{ Selectivity (\%) } \\
\hline & & & & acetaldehyde & $\begin{array}{l}\text { diethyl } \\
\text { ether }\end{array}$ & $\begin{array}{l}\text { ethyl } \\
\text { acetate }\end{array}$ & 1-butanol & $\begin{array}{c}\text { 1,1-diethoxy } \\
\text { ethane }\end{array}$ \\
\hline Crossfield & $20 \% \mathrm{Ni} / \mathrm{Al}_{2} \mathrm{O}_{3}$ & HTC-500 & 5 & 5 & 7 & 4 & 62 & 3 \\
\hline La Roche & $20 \% \mathrm{Ni} / \mathrm{Al}_{2} \mathrm{O}_{3}$ & Self-prepared & 18 & 43 & 5 & 4 & 37 & 11 \\
\hline
\end{tabular}

Figure 3. TEM and XRD pictures of self-prepared $\mathrm{Ni} / \mathrm{Al}_{2} \mathrm{O}_{3}$ catalyst. Based on the results it can be seen that both $\mathrm{Ni}$ and $\mathrm{NiO}$ are found with average particle sizes of $\sim 4 \mathrm{~nm}$ for both phases.
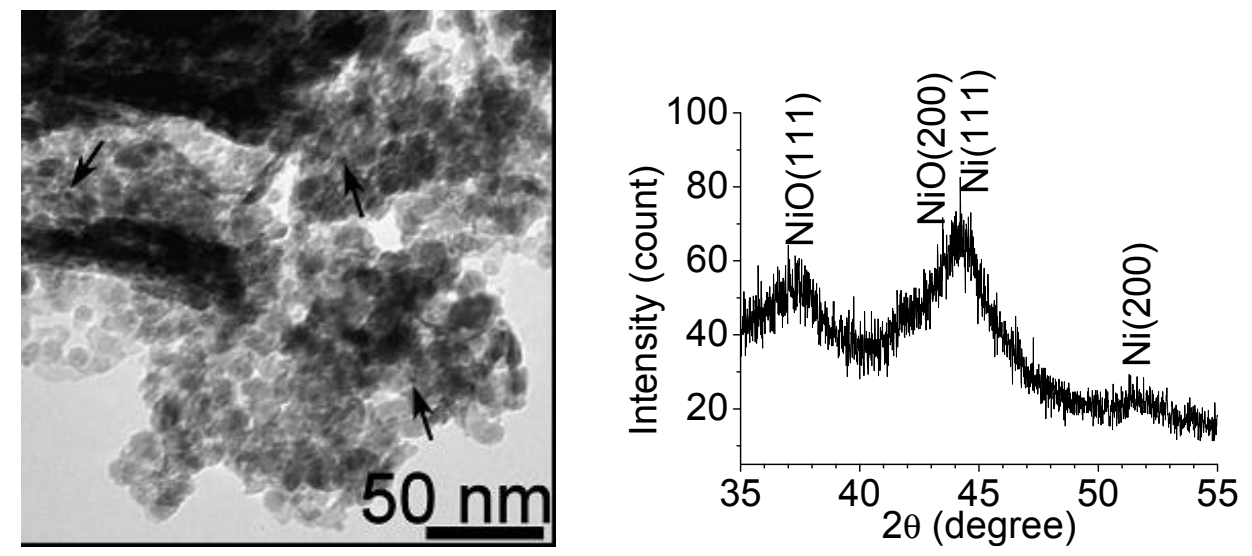

Figure 4. TEM and XRD images of the commercial model catalyst $20.7 \mathrm{wt} \% \mathrm{Ni} / \mathrm{Al}_{2} \mathrm{O}_{3}$ HTC-500. The average particle size was found to be about twice as much as for the self-made Ni-catalyst and showed considerably broad size dispersion.
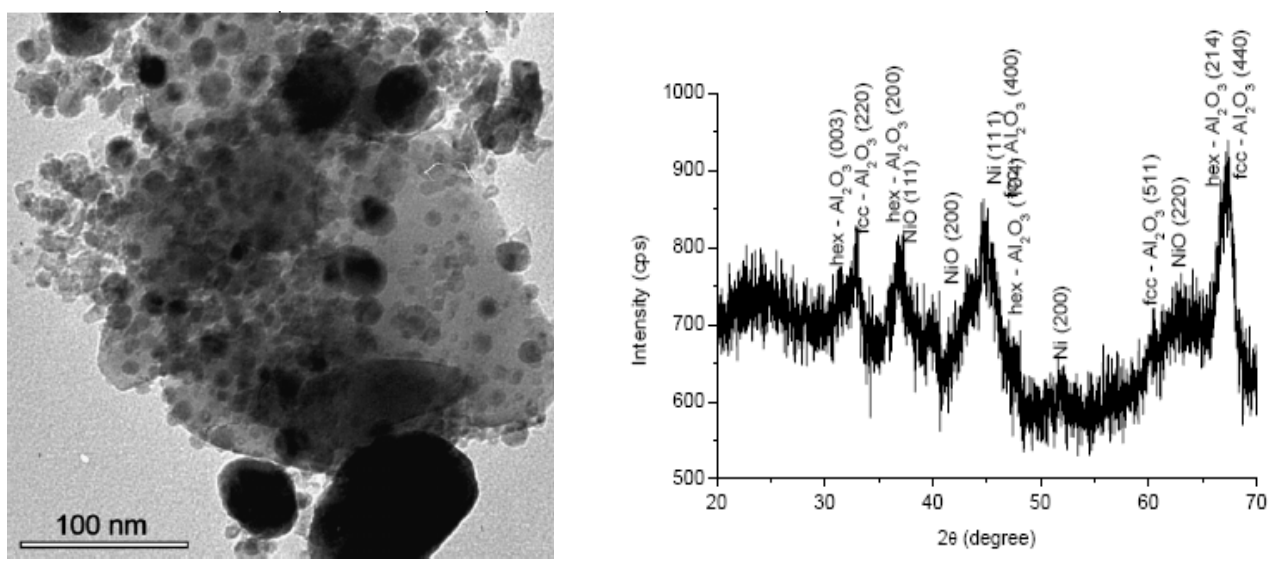

Au: The commercial gold catalyst showed an interesting behavior by producing a moderate selectivity to 1-butanol (35\%) and also some amounts of acetaldehyde, ethyl acetate and diethyl 
acetate (Table 9). This might be due to the ability of gold to promote different and simultaneous reaction pathways.

Table 9. Results obtained with alumina supported Au catalyst.

\begin{tabular}{|c|c|c|c|c|c|c|c|c|}
\hline \multirow[b]{2}{*}{ Manufactured } & \multirow[b]{2}{*}{ Catalyst } & \multirow[b]{2}{*}{$\begin{array}{l}\text { Product } \\
\text { code }\end{array}$} & \multirow[b]{2}{*}{$\begin{array}{c}\text { Conversion } \\
(\%)\end{array}$} & \multicolumn{5}{|c|}{ Selectivity (\%) } \\
\hline & & & & acetaldehyde & $\begin{array}{l}\text { diethyl } \\
\text { ether }\end{array}$ & $\begin{array}{l}\text { ethyl } \\
\text { acetate }\end{array}$ & 1-butanol & $\begin{array}{l}\text { 1,1-diethoxy } \\
\text { ethane }\end{array}$ \\
\hline Mintek & $0.8 \% \mathrm{Au} / \mathrm{Al}_{2} \mathrm{O}_{3}$ & $\mathrm{BC} 3$ & 6 & 18 & 31 & 15 & 35 & 0 \\
\hline
\end{tabular}

\subsection{Validation of the Bomb Reactor Screening Experiments}

The reproducibility of the experiments was controlled by repeating experiments with same catalyst at least twice. For each and every test batch of eight (8) mini-bomb reactors, a reference catalyst was used to control the experimental reproducibility. When the product distribution obtained in mini-bomb reactors was compared with the products obtained in the Parr autoclave, under similar conditions and with the same catalyst, it was evident that analogous results were obtained, i.e., the process is scaleable.

Out of all screened catalysts, the catalyst HTC-500 $(20.7 \% \mathrm{Ni}$ on alumina) was clearly the best one giving a good conversion $(\mathrm{X}=5 \%)$ and highest selectivity $\left(\mathrm{S}_{\text {butanol }}=62 \%\right)$ in the whole series. Nevertheless, it is expected that after optimizing catalyst properties and reaction conditions, the selectivity, activity and ethanol conversion could be notably improved.

\subsection{Kinetics and Mechanistic Studies with HTC-500 (20.7\% Ni on Alumina)}

Based on the results from the screening experiments (Tables 3-9) commercial Ni/ $/ \mathrm{Al}_{2} \mathrm{O}_{3}(\mathrm{HTC}-500)$ was chosen for further studies in batch reactor.

The reaction kinetics was investigated in the $300 \mathrm{~mL}$ Parr autoclave using the identical catalyst-to-ethanol ratio as in the miniature bomb reactors. Commercial (Crosfield HTC-500, 20.7\% Ni on alumina) catalyst was used in the experiments. The temperature profile in the larger batch reactor during the reaction was similar consisting of 15-20 min heating period after which an isothermal reaction was carried out at $250{ }^{\circ} \mathrm{C}$. Analysis of samples taken at time zero and at the time when the desired reaction temperature was reach revealed that negligible ethanol conversion took place during the short (15-20 $\mathrm{min}$ ) reactor heating step. A representative kinetic plot is illustrated in Figure 5 which shows the conversion of ethanol and the selectivity of 1-butanol among liquid carbon products as a function of time. Moreover, the behavior of side products concentration evolvement is illustrated in Figures 6 and 7, respectively. Interestingly, the behavior of acetaldehyde and 1,1-diethoxy ethane follow a different pattern than that of ethyl acetate, butyraldehyde, diethyl ether and 1-hexanol. Concentrations of the later mentioned by-products illustrate a stable upward trend whereas acetaldehyde and 1,1-diethoxy ethane concentrations seem to peak in early stages of the reaction followed by a sharp decrease. It might be that acetaldehyde and 1,1-diethoxy ethane have a remarkable effect on the reaction in question. The larger scale $(300 \mathrm{~mL}$ instead of $2 \mathrm{~mL})$ autoclave allowed sampling of the liquid-phase during the course of the reaction under controlled temperature and pressure. The gas-phase composition could be analyzed by MS after the reaction. When the 
experiments were repeated over the same catalyst it was observed that the reproducibility of the results was within $1 \%$.

Figure 5. Valorization kinetics of ethanol to 1-butanol over a Ni catalyst (HTC-500) in the batch reactor. Reaction conditions: $250{ }^{\circ} \mathrm{C}, 70$ bar. Selectivity calculated among liquid carbon products.

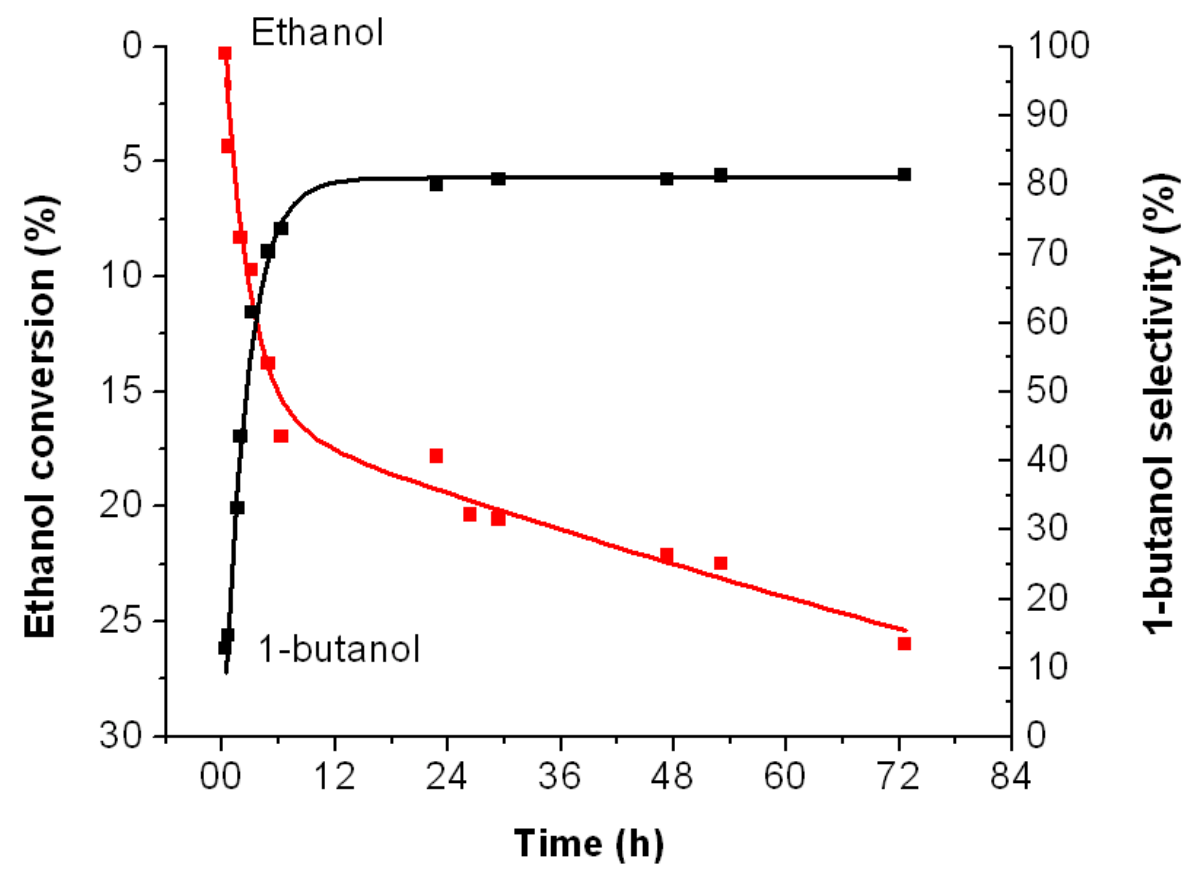

Figure 6. Ethyl acetate, 1-hexanol, diethyl ether and butyraldehyde concentrations as a function of time.

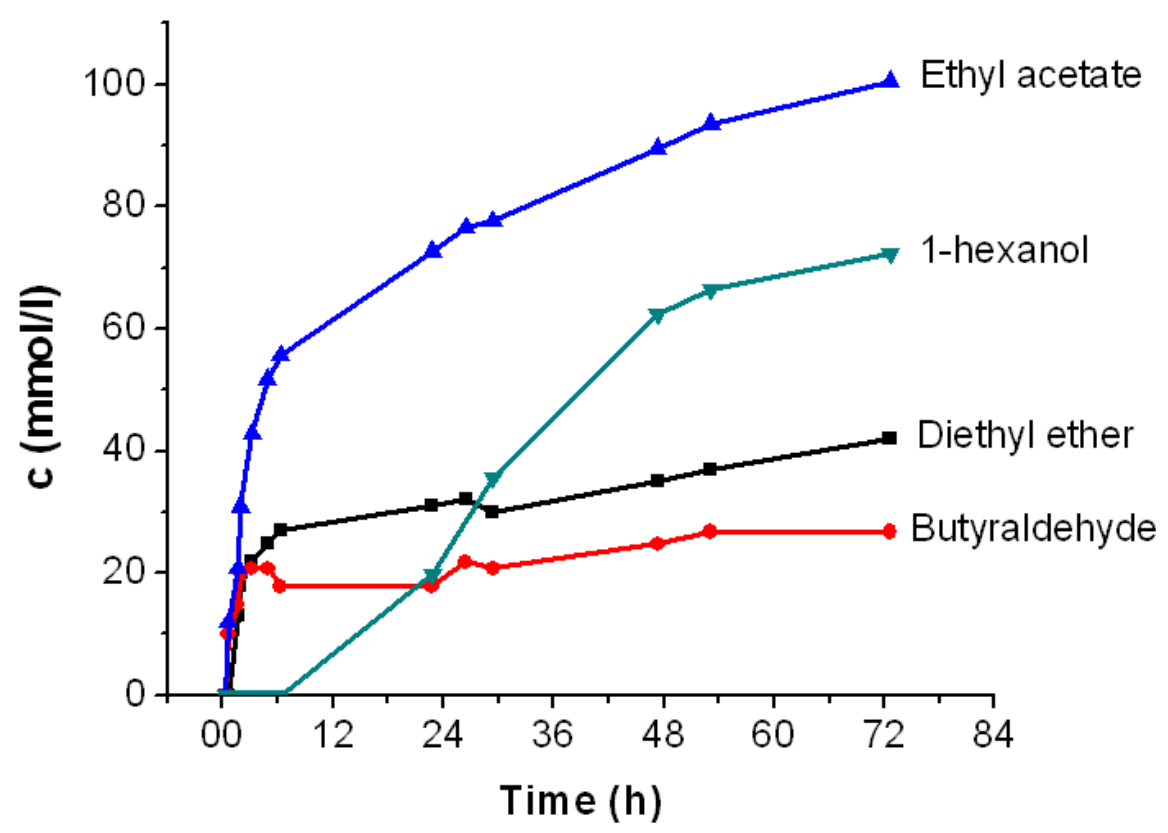


Figure 7. Acetaldehyde and 1,1-diethoxy ethane concentrations plotted as the function of time.

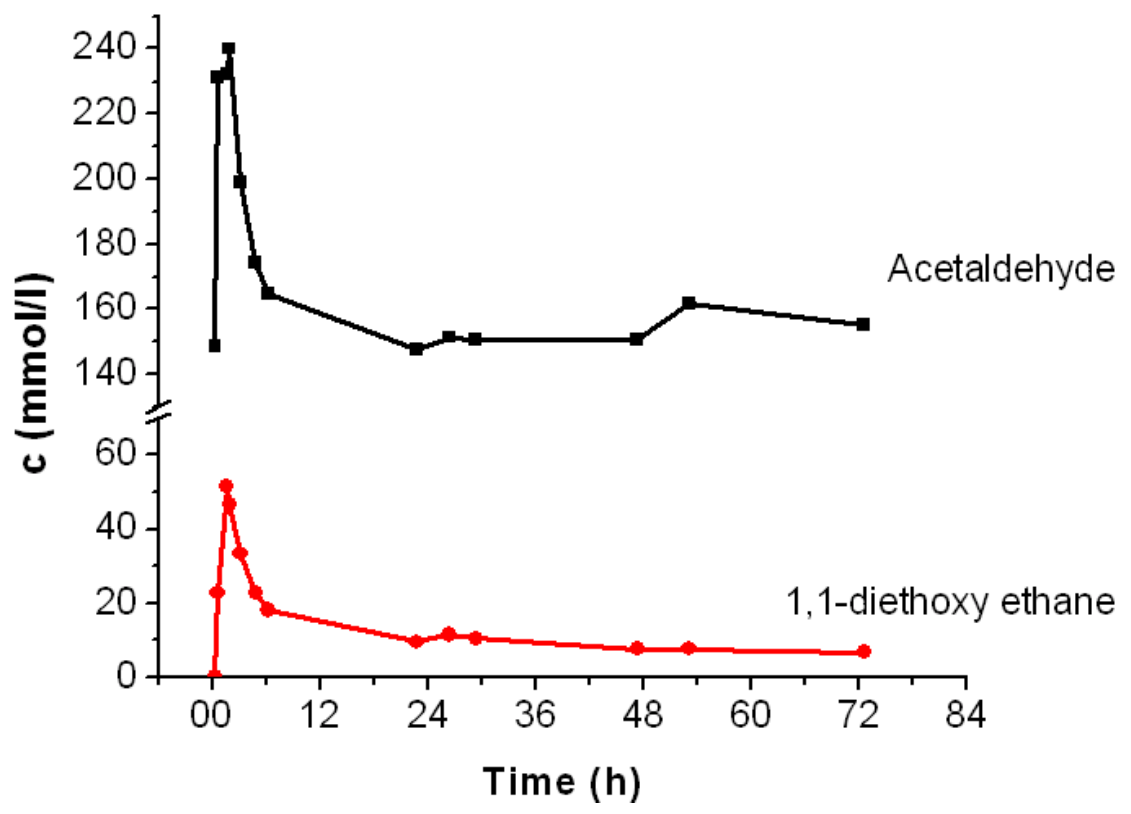

\subsubsection{Gas-Phase Analysis after the Reaction}

After heating the reactor to $250{ }^{\circ} \mathrm{C}$, the pressure started gradually to increase from 76 bar to about 83 bar after which pressure remained virtually constant. The gas-phase analysis was conducted after the reactor was cooled down to room temperature (RT). At RT, the residual gas-phase was analyzed by a mass spectrometer (the gas-phase composition was similar in all carried experiments over the HTC-500). It was found that the gas composition was roughly $2 / 3$ of hydrogen and $1 / 3$ of methane. Only traces of carbon monoxide and carbon dioxide were found.

During the course of the reaction, gaseous hydrogen $\left(\mathrm{P}_{\text {hydrogen }}=4\right.$ bar) that might promote hydrogenation of the intermediate products, was formed in the reactor. The chosen Ni/alumina catalyst is a known good catalyst for $\mathrm{C}=\mathrm{O}$ and $\mathrm{C}=\mathrm{C}$ bond hydrogenations. Moreover, it is also suggested that nickel might promote $\mathrm{C}-\mathrm{C}$-bond breaking of the ethanol molecule. Thus, this would lead to the emergence of hydrogen and methane [17]. Consequently, the previously proposed reaction sequence starting from dehydration of ethanol to acetaldehyde followed by aldol condensation and subsequent hydrogenation to 1-butanol sounds logical. However, in mechanistic studies when various amounts of acetaldehyde was present, the "promoting effect" could not be detected. Presence of acetaldehyde produced a lot of by-products (a total of 50-80 products) which could not be properly separated or identified.

The role of hydrogen was investigated in more detail by inserting known amounts of hydrogen in the reactor. Based on experiments at different initial hydrogen pressures, it could be concluded that the reaction rate decreased with increasing initial hydrogen pressure. Another point, which is related to the formation of gaseous hydrogen during the reaction, is that in the kinetic experiments the ethanol conversion $v s$. time curve and the hydrogen pressure vs. time curve follow an identical trend. It would be a plausible explanation that the in-situ formed hydrogen is inhibiting the ethanol dimerization reaction which proceeds well over an oxidized catalyst. The effect of initial hydrogen pressure to 1-butanol formation is presented in Figure 8 as a function of time. 
Figure 8. The effect of different initial hydrogen pressures to the forming amounts of 1-butanol.

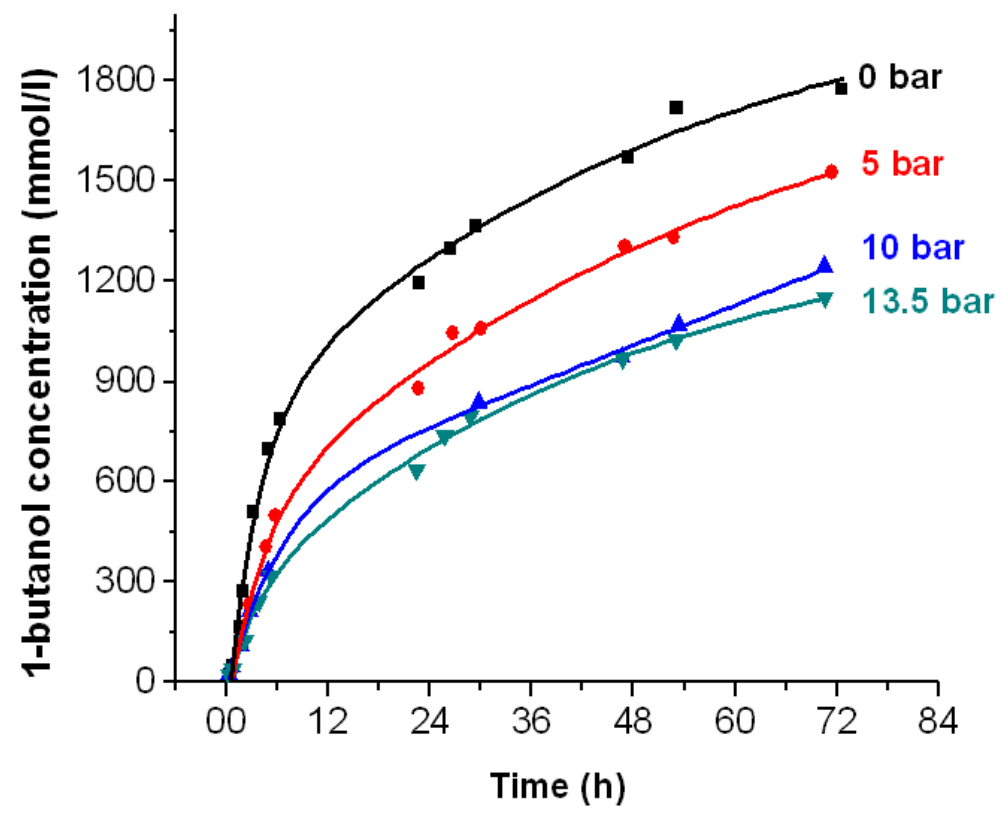

\subsubsection{Catalyst Pretreatment}

HTC-500 catalyst was reduced at $400{ }^{\circ} \mathrm{C}$ (maximum temperature for the reactor setup) under hydrogen for $3 \mathrm{~h}$ or used as received. The influence of added oxygen ( 3 bar) was also tested. The catalyst activity was independent on the pretreatments employed here. Selectivity towards diethyl ether was notably increased by a reductive pretreatment, simultaneously lowering the selectivity towards 1-butanol (Figure 9). The added oxygen had no detectable influence on the reaction. It seems that the $\mathrm{Ni}$ /alumina catalyst gives the highest selectivity when used without any reduction in the oxidized state.

Figure 9. Effect of catalyst pretreatment on diethyl ether formation over a $\mathrm{Ni}$ catalyst (HTC-500) in the bath reactor. Reaction conditions: $250^{\circ} \mathrm{C}, 70$ bar.

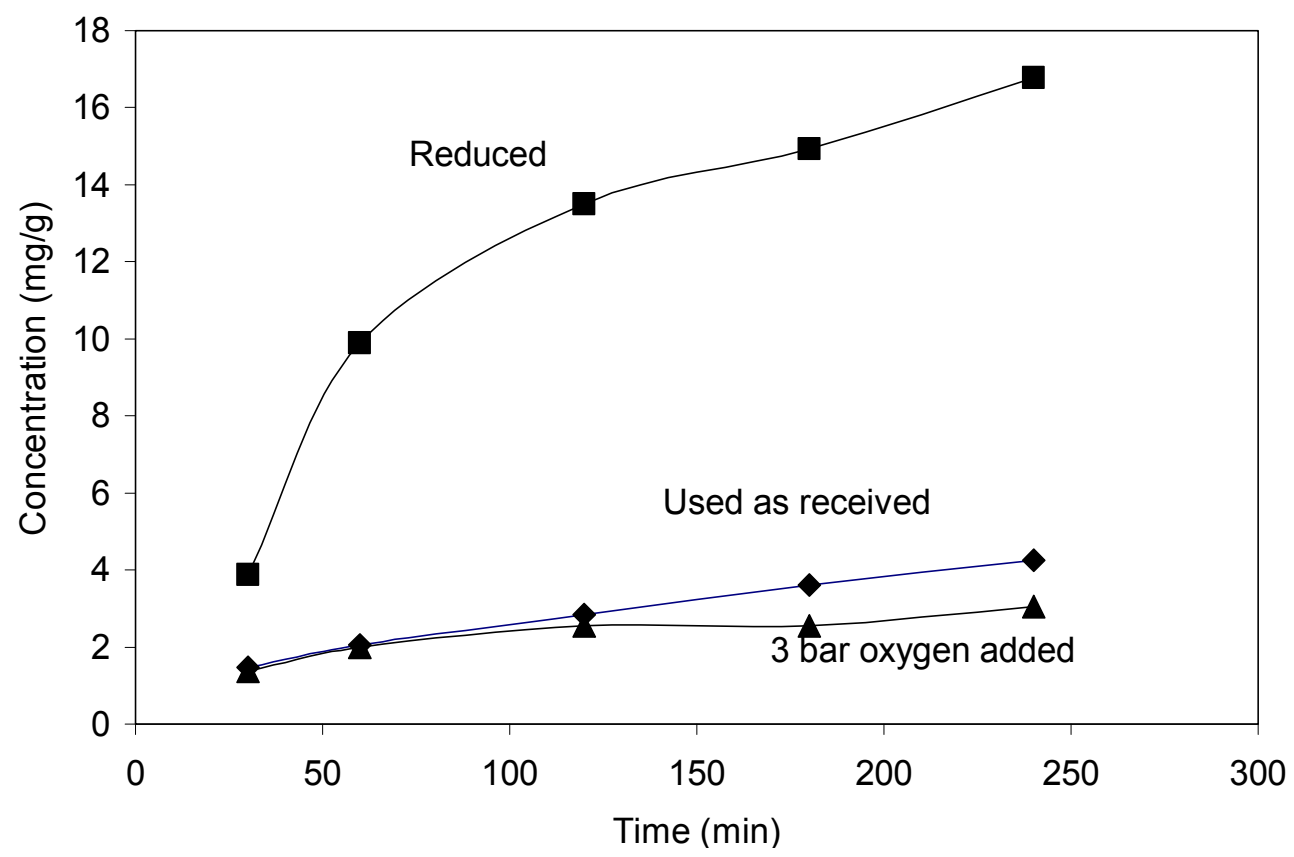




\subsubsection{By-Product Formation}

Formation of by-products, i.e., acetaldehyde, diethyl ether, ethyl acetate and 1,1-diethoxyethane, can be explained by commonly known organic reactions [18] taking place under reaction conditions applied in the present work. Acetaldehyde is expected to emerge from the dehydrogenation of ethanol according to Scheme 2. At the same time, it also results in the formation of hydrogen that was experimentally observed as the major gaseous product. Diethyl ether is formed via a reaction of ethanol to ether and water (Scheme 3). In addition, ethyl acetate was formed over Au catalyst. In accordance to the Scheme 4, it is evident that the formation of an ester requires the formation of a carboxylic acid via oxidation of the alcohol. Au is a good oxidation catalyst which might explain the prominent ethyl acetate formation. Acetic acid was not detected in the GC analysis. However, it is possible that under our experimental conditions acetic acid immediately reacted to the corresponding ester. Finally, 1,1-diethoxyethane was formed via the acid catalyzed acetalisation of acetaldehyde and ethanol (Scheme 5). Most of these side reactions (excluding dehydrogenation of ethanol) formed water as a by-product. Still, also the target reaction forms 1-butanol and water. Therefore, it was of interest to study water removal during reaction. This will be discussed next.

Scheme 2. Dehydrogenation of ethanol.

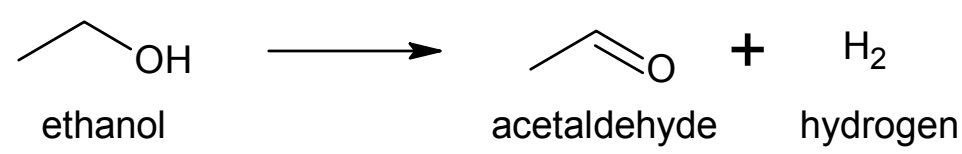

Scheme 3. Formation of diethyl ether from ethanol.

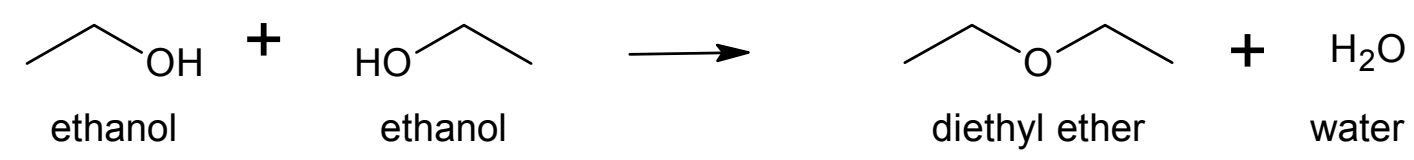

Scheme 4. Two step reaction sequence forming ethyl acetate from ethanol.<smiles>CCOC(=O)OCC(=O)O</smiles><smiles>CCOC(=O)OCC</smiles> 
Scheme 5. Acetalisation of acetaldehyde and ethanol.

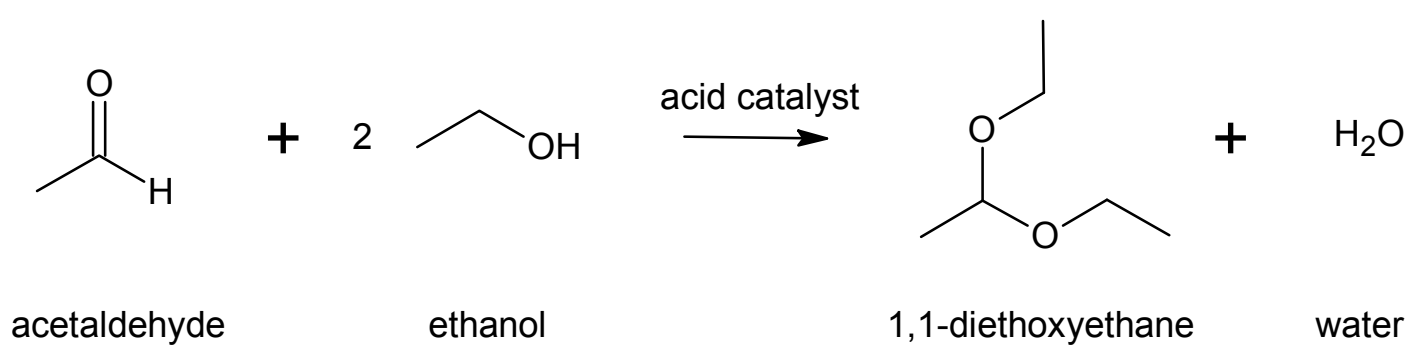

\subsubsection{Water Removal from the Reaction Mixture}

In a typical reaction sequence (Figure 6), we can clearly see that the ethanol conversion under studied conditions stabilized at a level around $20 \%$ (batch reactor experiments). In principle, the reactant conversion can be limited by catalyst deactivation or equilibrium limitations emerging, e.g., by the presence of formed water. A third aspect of water is the steam reforming of ethanol to hydrogen over nickel metal catalysts [19]. In the presence of water, ethanol and a Ni catalyst, hydrogen is formed. Therefore, the formation of hydrogen (via steam reforming reaction) might be a plausible explanation for the promoting role of water removal. The net reaction is dimerization of two ethanol molecules to 1-butanol and water (Scheme 1). Therefore, the removal of water was of interest. The reaction was carried out with pre-dried ethanol using $3 \AA$ molecular sieves. The same molecular sieves were also added into the reactor to enable water removal during the reaction. The water removal procedure resulted in significant improvement of the ethanol conversion from $20 \%$ to $30 \%$. This would indicate that the reactant conversion can be enhanced by water removal.

\subsubsection{Thermodynamic Calculations}

In order to distinguish if the obtained maximum ethanol conversions levels (20-30\%) are due to catalyst deactivation by the in situ formed hydrogen or due to equilibrium limitations, the equilibrium composition for the main reaction was calculated. Based on the calculations under our reaction conditions at $250{ }^{\circ} \mathrm{C}$ and 70 bar, the theoretical maximum conversion of ethanol to 1-butanol was found to be $98.5 \%$. Therefore, we suggest that the reason for the attained $30 \%$ ethanol conversion is catalyst deactivation under reactions conditions (due to in situ formed hydrogen) rather than equilibrium limitations.

\subsubsection{Other Alcohols as Reactants}

The performance of the catalytic system was evaluated in mini-bomb screening reactors using methanol, ethanol, 1-propanol and 1-butanol as reactants over the HTC-500 catalyst. Interestingly, under studied conditions $\left(250^{\circ} \mathrm{C}\right)$, only ethanol seems to produce $n$-alcohol dimerisation products. The inactivity of methanol might be due to the difficult methanol dehydration (water removal) when compared to longer chain alcohols. The mechanism accounting for the dimerisation of ethanol to 1-butanol should be able to explain the specificity of the reaction to ethanol but not, e.g., 1-propanol and 1-butanol as reactants. One such mechanistic proposal was proposed by Suchida et al. [14] where the Guerbet alcohols formed predominantly from ethanol yield linear alcohol products (1-butanol) 
whereas reactions involving longer alcohols $\left(\mathrm{C}_{3}, \mathrm{C}_{4}, \ldots\right)$ result in the formation of branched Guerbet alcohols.

\subsubsection{The Effect of Sub- vs. Super-Critical Conditions}

For the next step, we studied whether super-critical conditions could be advantageous in the investigated reaction. The tests were performed by means of the above mentioned mini-reactors at the temperatures below and over $240{ }^{\circ} \mathrm{C}$ which is approximately the triple point of ethanol. The test method was exactly the same as previously mentioned while the only difference was the temperature. However, the results indicated, that at least in our case, we could not find any beneficial effects related to super-critical conditions. The product distribution was the similar under sub- and super-critical conditions. Furthermore, several authors' calculations indicate [20-22] that ethanol hydrogen bonding properties change significantly under super-critical conditions.

\section{Experimental Section}

\subsection{Catalyst Screening}

Catalyst screening was carried out in small, $2 \mathrm{~mL}$ isobaric mini-reactors equipped with magnetic stirring (Figure 10). The reactors were made of stainless steel and could be used for the reaction carried out at pressures up to 100 bar and temperature up to $250{ }^{\circ} \mathrm{C}$ (maximum for the Teflon coated stirrer magnet). The catalyst testing procedure was as follows: the reactor was loaded with the catalyst (10 or $50 \mathrm{mg}$ ) and ethanol (Etax Aa, 99.5\%, $1.5 \mathrm{~mL}$ ) under inert atmosphere (He) in a glove bag. The reactors were closed and placed in the heating unit allowing 8 reactors to be run simultaneously. The reactors were heated to $250{ }^{\circ} \mathrm{C}$ with a heating rate of $20{ }^{\circ} \mathrm{C} / \mathrm{min}$. The reaction was allowed to proceed for $3 \mathrm{~h}$. After reaction, the reactors were rapidly quenched (cooled down) in a water bath and the liquid contents were analyzed by gas chromatography (GC). While opening the reactors, it was noted that in many cases notable gas formation had taken place during the experiment (sealed reactors). The gas-phase composition could not be analyzed in the catalyst screening mode; however, it could be done during the kinetic experiments carried out in the standard high pressure Parr autoclave.

Figure 10. Reactors used for catalyst screening $\left(V_{\text {reactor }}=2 \mathrm{~mL}\right)$.

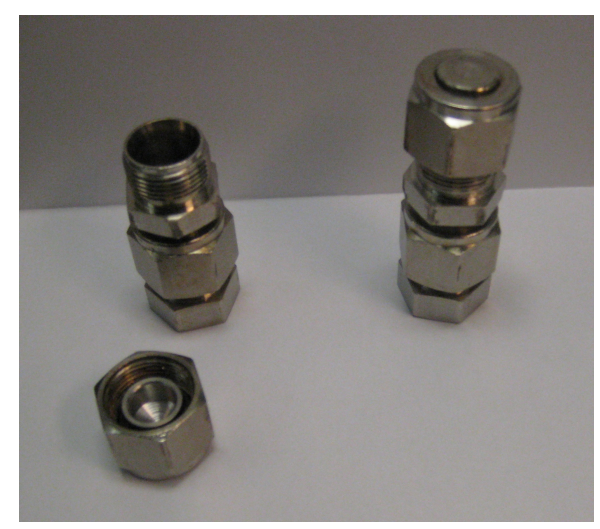




\subsection{Kinetic Experiments}

Proper kinetic experiments were carried out in a $300 \mathrm{~mL}$ high pressure Parr autoclave equipped with a mechanical Rushton turbine type of a stirrer. The reactor was loaded with the catalyst (typically $3.3 \mathrm{~g})$ and flushed with inert gas $(\mathrm{He})$. In some experiments, catalyst reduction under flowing hydrogen, at $400{ }^{\circ} \mathrm{C}$ for $3 \mathrm{~h}$, was carried out. The catalyst-to-reactant molar ratio was identical as in the case of catalyst screening experiments in small mini-autoclaves. The ethanol reactant $(100 \mathrm{~mL})$ was degassed for $10 \mathrm{~min}$ with inert gas before injection to the reactor. The reactor was heated rapidly to $250{ }^{\circ} \mathrm{C}$ and the reaction was monitored by taking small liquid samples $(0.5 \mathrm{~mL})$. The gas-phase composition was analyzed at the end of the reaction after cooling the reactor back to room temperature (RT). Gas chromatographic analysis (Agilent, DB-Petro $100 \mathrm{~m}$ column) was calibrated with commercial standards. The initial compound identification was based in GC-MS identification of the peaks using the same column. The semi-quantitative gas phase analysis was based on a quadrupole mass spectrometer (Balzers). The stirring rate applied throughout the the matrix of catalytic experiments was $1500 \mathrm{rpm}$ thus ensuring that we resided in the kinetic regime. Due to the fact that only liquid reactants (ethanol) were used and that the reaction rates were rather low, the danger of external mass transfer limitations can be regarded as negligible.

\subsection{Catalysts}

A total of 13 catalysts were studied in the present work. Both in-house prepared and commercial catalyst were used. For commercial catalysts, the available characterization data can be found in Table 2, whereas in the case of in-house prepared ones the catalyst preparation is described below and the characterization results are reported in Table 2.

\subsection{Analytical Procedure}

The liquid-phase analysis was carried out with an Agilent Technologies, $6890 \mathrm{~N}$ gas chromatograph (GC) equipped with a DB-Petro $(122-10 \mathrm{~A} 6,100 \mathrm{~m}$, i.d. $0.250 \mathrm{~mm})$ column. The products were identified by means of an Agilent gas chromatograph coupled to a mass spectrometer (GC-MS) equipped with the same column. Calibration of the GC was carried out with commercial standards using octane (Fluka $>99 \%$ ) as internal standard. The calibration was carried out using the following commercially available chemicals: ethanol (Altia 99.5\%, Aa), butyraldehyde (Lancaster, 99\%), diethyl ether (Merck, max 0.0075\% $\mathrm{H}_{2} \mathrm{O}$ ), ethyl acetate (Fluka, >99.5\%), 1-butanol (Acros Organics, 99\%), 1,1-diethoxy ethane (Fluka, $\geq 95 \%$ ), 1-hexanol (Fluka, $\geq 99 \%$ ), 1-octanol (Riedel-de Haën, $\geq 99.5 \%$ )

The qualitative gas-phase analysis was carried out with a quadrupole MS. After cooling down the reactor contents to room temperature (RT), the remaining gas phase was analyzed with MS.

\subsection{Catalyst Characterization}

Thirteen (13) different catalysts were tested in the screening phase. The catalysts were characterized with TEM, XRD, physisorption and chemisorption. To identify crystal phase and size of the catalyst (and in some cases of the support) X-ray diffraction analyses were carried out using $\mathrm{Cu} \mathrm{K \alpha}$ radiation (Siemens D5000 diffractometer equipped with a graphite monochromator to suppress fluorescent and 
$\mathrm{Cu} \mathrm{K} \beta$ radiation). The average crystallite size of catalyst particles was estimated using Scherrer's equation from the halfwidths of the most intensive reflections. Transmission electron microscopy (LEO 912 OMEGA, energy-filtered TEM, $120 \mathrm{kV}$ ) has been used to study microstructure and particle size of catalyst samples. Histograms of particle size distribution were obtained by counting typically 100 particles on the micrographs.

\subsection{Thermodynamic Calculations}

The equilibrium composition for the main reaction, i.e., 2 ethanol $=1$-butanol + water was calculated in order to check if the conversion would be equilibrium limited. The calculations were performed with the software PRO/II (PRO/II 8.3 invensys Systems, Inc.) using the Gibbs reactor module. At $250{ }^{\circ} \mathrm{C}$ and 70 bar the conversion of ethanol to 1-butanol was found to be $98.5 \%$.

\section{Conclusions}

Several heterogeneous alumina supported metal catalysts were screened in the direct liquid phase one-pot conversion of ethanol to 1 -butanol. For the most promising catalyst $\left(20.7 \% \mathrm{Ni} / \mathrm{Al}_{2} \mathrm{O}_{3}\right.$, HTC-500), a $25 \%$ ethanol conversion with $80 \%$ selectivity to 1-butanol could be reached. Based on the results achieved, the investigated metals can be ranked in terms of the selectivity towards 1-butanol as follows: $\mathrm{Ni}>\mathrm{Pt}>\mathrm{Au} \sim \mathrm{Rh}>\mathrm{Ru}>>\mathrm{Ag}$. Additionally, the results achieved indicate that the most plausible reaction pathway follows the Guerbet route. The reaction was specific to dimerisation of ethanol. Linear $n$-alcohols could not be produced from methanol, 1-propanol, or 1-butanol as the reactants. This reaction has a great potential in overcoming disadvantages of bioethanol and serving as yet another step toward wider portfolio of sustainable transportation fuels. We will attempt to optimize the catalyst characteristics in the quest towards the optimal 1-butanol selectivity. Also, on-going experiments with a new continuous operating fixed bed reactor designed at operating in the liquid phase conditions will be utilized.

\section{Acknowledgments}

This work is part of the activity at the Åbo Akademi Process Chemistry Centre within the Finnish Centre of Excellence Programme (2006-2011) of the Academy of Finland. Financial support from the Academy of Finland (project Susfuflex) is gratefully acknowledged. In Sweden, the Bio4Energy programme is acknowledged. A.-R. Leino is grateful for the postgraduate student position from GETA and for the personal grant received from the Riitta and Jorma J. Takanen foundation.

\section{References}

1. Lange, J.P. Catalysis for Renewables; Centi, G., Santen, R., Eds.; Wiley-VCH: Wenheim, Germany, 2007.

2. Chheda, J.N.; Huber, G.W.; Dumesic, J.A. Liquid-phase catalytic processing of biomass-derived oxygenated hydrocarbons to fuels and chemicals. Angew. Chem. Int. Ed. 2007, 46, 7164-7183.

3. Corma, A.; Iborra, S.; Velty, A. Chemical routes for the transformation of biomass into chemicals. Chem. Rev. 2007, 107, 2411-2502. 
4. Gautam, M.; Martin, D.W., II. Combustion characteristics of higher-alcohol/gasoline blends. J. Power Energ. 2000, 214, 497-511.

5. Falbe, J. New Syntheses with Carbon Monoxide; Springer-Verlag: Berlin, Germany, 1980.

6. Wilkinson, G.; Gordon, F.; Stone, A.; Abel, E.W. Comprehensive Organometallic Chemistry, The Synthesis, Reactions and Structures of Organometallic Compounds; Pergamon Press: New York, NY, USA, 1981.

7. Cornils, B.; Wiebus, E. Aqueous organic reactions. Chemtech 1995, 25, 33-38.

8. Cornils, B.; Kuntz, E.G.J. Introducing TPPTS and related ligands for industrial biphasic processes. J. Organomet. Chem. 1995, 502, 177-186.

9. Wiebus, E.; Cornils, B. Water soluble catalysts improve hydroformulation of olefins. Hydrocarb. Process. 1996, 75, 63-66.

10. Lenerda, M.; Storaro, L.; Ganzerla, R. Hydroformulation of simple olefins catalyzed by metals and clusters supported on unfunctionalized inorganic carriers. J. Mol. Catal. A 1996, 111, 203-237.

11. Tsuchida, T.; Sakuma, S.; Takeguchi, T.; Ueda, W. Direct synthesis of n-butanol from ethanol over nonstoichiometric hydroxyapatite. Ind. Eng. Chem. Res. 2006, 45, 8634-8642.

12. Yang, K.W.; Jiang, X.Z.; Zhang, W.C. One-step synthesis of n-Butanol from ethanol condensation over alumina-supported metal catalysts. Chin. Chem. Lett. 2004, 15, 1497-1500.

13. Yang, C.; Meng, Z. Bimolecular condensation of ethanol to 1-butanol catalyzed by Alkali Cation Zeolites. J. Catal. 1993, 142, 37-44.

14. Ndou, A.S.; Plint, N.; Coville, N.J. Dimerisation of ethanol to butanol over solid-base catalysts. Appl. Catal. A Gen. 2003, 251, 337-345.

15. Tsuchida, T.; Kubo, J.; Yoshioka, T.; Sakuma, S.; Takeguchi, W.; Ueda, W. Reaction of ethanol over hydroxyapatite affected by Ca/P ratio of catalyst. J. Catal. 2008, 259, 183-189.

16. Joris, S.J.; Amberg, C.H. Nature of deficiency in nonstoichiometric hydroxyapatites. J. Phys. Chem. 1971, 75, 3167-3171.

17. Kratochwil, T.; Wittmann, M.; Kuppers, J. Adsorption of ethanol on Ni(100) surfaces. J. Electron Spectrosc. Relat. Phenom. 1993, 64/65, 609-617.

18. McMurry, J.; Simanek, E. Fundamentals of Organic Chemistry, 6th ed.; Thomson Brooks/Cole: Pacific Grove, CA, USA, 2007.

19. Wang, W.; Wang, Y. Steam reforming of ethanol to hydrogen over nickel metal catalysts. Int. J. Energy Res. 2010, 34, 1285-1290.

20. Eckert, C.; Liotta, E.; Boughner, E.; Lu, J. Nearcritical and supercritical ethanol as a benign solvent: Polarity and hydrogen-bonding. Fluid Phase Equilibria 2002, 198, 37-49.

21. Yang, J.; Zhang, Y.; Yu, Y.-X.; Li, Y.-G. Structural and hydrogen bond analysis for supercritical ethanol: A molecular simulation study. J. Supercrit. Fluids 2005, 36, 145-153.

22. Samios, J., Dellis, D.; Chalaris, M. Pressure and temperature dependence of the hydrogen bonding in supercritical ethanol: A computer simulation study. J. Phys. Chem. B 2005, 109, 18575-18590.

(C) 2012 by the authors; licensee MDPI, Basel, Switzerland. This article is an open access article distributed under the terms and conditions of the Creative Commons Attribution license (http://creativecommons.org/licenses/by/3.0/). 